\title{
A formação e o povoamento do município de Porto Alegre do Norte/MT: um olhar sobre as relações sociais e culturais
}

The training and people of Porto Alegre do Norte /MT: a look at social and cultural relations

\author{
Jheine Ribeiro Santos \\ Graduanda em Sistema de Informação UNEMAT \\ E-mail: jheyne2014@hotmail.com
}

Maria do Rosário Soares Lima

Mestra em História pela UFMT

Professora na UNEMAT e E. E. Vila Rica-SEDUC MT

E-mail: mariadorosariovilarica@gmail.com

Resumo: Este texto é parte dos resultados de uma pesquisa realizada sobre os elementos históricos que constituem o processo de formação do município de Porto Alegre do Norte, localizado na região nordeste do estado de Mato Grosso, também denominada de Microrregião Norte Araguaia. Trata-se de uma pesquisa fundamentada nos pressupostos teóricos e metodológicos da história oral, pois além das análises dos documentos escritos, icnográficos, fez -se diversas entrevistas com os antigos moradores do município, as quais possibilitaram uma melhor compreensão acerca dos artifícios que compõem a dinâmica de reocupação de terra na região. Sendo assim, o nosso texto tem como função destacar os conflitos e as estratégias de luta dos posseiros, frente às ameaças e violências praticadas pelos fazendeiros na disputa pela posse da terra. Através desse estudo pôde-se perceber que esses conflitos de terra foram um longo e doloroso processo para os posseiros, que na época, habitavam a região, hoje conhecida como Porto Alegre do Norte. Lugar esse onde os posseiros enfrentaram diversos desafios, desde os conflitos com os fazendeiros e com os povos indígenas que habitavam a região.

Palavras chave: Memória. Conflitos de Terra. Cultura.

Abstract: : This text is part of the results of a research carried out on the historical elements that constitute the process of formation of the municipality of Porto Alegre do Norte, located in the northeastern region of the state of Mato Grosso, also called the Northern Araguaia Microregion. This is a research based on the theoretical and methodological assumptions of oral history, because besides the analysis of written, icnographic documents, several interviews were conducted with the former residents of the municipality, which allowed a better understanding about the artifices that make up the land reoccupation dynamics in the region. Thus, our text has the function of highlighting the conflicts and strategies of the squatters' struggle, in face of the threats and violence practiced by the farmers in the dispute for the possession of the land. Through this study we could see that these land conflicts were a long and painful process for the squatters, who at that time inhabited the region, now known as Porto Alegre do Norte. This place where the squatters faced several challenges, since the conflicts with the farmers and with the indigenous peoples that inhabited the region

Keywords: Memory. Earth Conflicts. Culture.

\section{Introdução}


Pensar o processo de formação e organização das cidades significa também refletir sobre as transformações que estas vêm passando ao longo do tempo. Isso vale não só para as grandes cidades como São Paulo, Rio de Janeiro e etc., mas também para as cidades menores.

Assim, a paisagem urbana aos poucos está sendo alterada, ao ganhar novas formas e evidências tangíveis; as transformações ocorridas se dão não apenas na dinâmica das relações sociais e culturais, mas também em função das diretrizes impostas pelo Estado no que tange aos arrolamentos de organização econômica, social e cultural, com implicações diretas na circulação e distribuição da riqueza, pautada muito mais na lógica da desigualdade econômica, do que no bem estar da população, desprovida de capital financeiro.

De acordo com Telles (2006), estamos convivendo diretamente, no dia a dia, com diversos processos em mutação, em que tudo parece estar a serviço da organização e do funcionamento do mercado de trabalho, por onde trilha a grande maioria das pessoas que vivem nas cidades, sejam estas pequenas ou grandes. Porém, as mudanças que se observam são tangíveis, mas nem por isso é simples explicar a dinâmica das transformações nas paisagens urbanas por meio de estudos de cunho sociológicos representados em diferentes fontes documentais (iconografia, relatos orais e registros oficiais e etc.).

Logo, segundo a autora, as transformações urbanas podem ser compreendidas a partir das escalas de distância e proximidade, entre aqueles lugares considerados perto ou longe do centro, e são essas que mudam e ditam os padrões de mobilidade e acesso não somente aos espaços urbanos, mas também aos seus serviços públicos e privados, bem como aos lugares de lazer.

Essas escalas de distanciamento agem sempre no sentido de reordenar a vida cotidiana, e ao mesmo tempo são atravessadas por um crescente universo de economia formal e informal, por uma imensa expressão da diversidade cultural de um povo. Ainda de acordo com Telles (2006, p.12), é possível afirmar que é neste contraste social que crescem a pobreza, o desemprego e a precariedade urbana, sobretudo, a violência, a fome e a miséria [...], pois "a morte violenta, a morte matada, como se diz em linguagem popular e a tragédia concentram-se nas periferias das cidades", [...] quando se passa a lidar com as proximidades dos motivos provocadores da pobreza e da criminalidade urbana.

Percebe-se que esses fatores dificultam a compreensão acerca dos acontecidos no interior das cidades, principalmente quando se versa sobre os artifícios do desenvolvimento econômico e da segurança pública. É sabido também, que esses fatores inferem diretamente na elaboração e no direcionamento das políticas públicas para as pessoas que vivem nos espaços urbanos, sejam eles das grandes ou de pequenas cidades. 
O que se sabe é que todas essas questões geram repercussão nos modos de viver e nas condições de trabalho, que estão cada vez mais precárias. Embora o governo realce que o emprego está em alta é comum vermos dados contestando e anunciando que o desemprego se prolonga.

Acredita-se que na medida em que estudos de cunho sociológico dão visibilidade às diferenças, sejam elas econômicas, sociais e culturais, facilita-nos a compreensão de como a sociedade se organiza e reage frente às mudanças que vão ocorrendo, ora de forma rápida, ora de forma lenta.

É a partir desta concepção que propomos apresentar uma breve contextualização histórica e sociológica compreendendo o período de surgimento, a configuração econômica, política e cultural atual do município de Porto Alegre do Norte, o qual está localizado na microrregião Norte Araguaia, situado à margem do rio Tapirapé e emancipado em 13 de maio de 1986.

Lembrando que a trajetória de ocupação e povoamento de Porto Alegre do Norte não foge às características de outros povoados do Araguaia, fundados nas décadas que antecedem os anos de 1980, uma vez que, a maior parte desses povoados é resultado dos conflitos e dos enfrentamentos na luta pela terra, em que muitos "posseiros" pagaram com a própria vida, ou dos amigos e familiares, o preço dessa luta, na qual buscavam adquirir uma pequena área de terra para morar e produzir o sustento de seus familiares.

Consideramos ainda ser importante destacar que os elementos teóricos e metodológicos que sustentam essa pesquisa que ora apresentamos parte dos resultados no decorrer do desenvolvimento do nosso texto, constituem-se nas estratégias de usos e análises de documentos escritos, icnográficos, mas principalmente das entrevistas realizadas com os antigos moradores do município.

Assim, destacamos a importância dos elementos teóricos que sustentam a fundamentam os princípios filosóficos e metodológicos dos estudos desenvolvidos sobre o uso de memória e fontes orais para as pesquisas direcionadas ao processo de compreensão da abordagem dada a dinâmica de formação e povoamento das cidades.

\section{Desenvolvimento}

Destarte, vale ressaltar que este texto tem como objetivo apresentar uma compreensão sobre o processo de formação e desenvolvimento do município de Porto Alegre do Norte- MT, destacando os conflitos e as estratégias de luta dos posseiros e fazendeiros pela posse da terra. Tal perspectiva é construída a partir das análises dos documentos inscritos e iconográficos, mas 
principalmente fazendo uso das narrativos que oriundas das entrevistas realizadas com os antigos moradores do município.

Por essa razão, consideramos ser relevante historizar o enfoque da abordagem sociológica, vinculado ao significado da luta e das estratégias de ocupação e reocupação da terra, visando sempre adquirir aparências das diferentes categorias sociais, inseridas no processo de povoamento do território do Araguaia-Xingu, para onde migraram pessoas oriundas de diferentes regiões do Brasil, as quais reocuparam essa região hoje denominada pelo Instituto Brasileiro de Geografia e Estatística - IBGE, como microrregião do Norte Araguaia.

O relato abaixo ajuda-nos ilustrar a trajetória feita por vários migrantes que reocuparam e formaram os diversos povoados dessa região:

[...] primeiramente houve o contato dos migrantes nordestinos, que chegavam atravessando o Rio Araguaia em busca da "bandeira verde" (de acordo com antigas profecias do Padre Cícero, os nordestinos deveriam ir para um suposto "sertão verde", que foi associado na época às matas da região do Araguaia). Esta população migrante logo encontrou os indígenas que habitavam a região, gerando os primeiros conflitos entre estes povos [...], (Ataíde, Morador de Porto Alegre do Norte-MT, Maio 2014').

Ao analisar o relato do morador observarmos que as pessoas vinham em busca de um local, do qual eles só ouviam falar sobre, esse lugar é também carregado de representações mitológicas. Portanto, pode-se notar que para o nosso narrador os migrantes oriundos dos estados da região Nordeste, buscavam encontrar as "Bandeiras verdes". Associando-se as terras do Araguaia ao misticismo das "Bandeiras Verdes", uma lenda da qual pouco se tem estudos realizados e dentre os estudiosos de migração que abordam essa questão, destaca-se José de Souza Martins (1996).

Mas ainda há os últimos resquícios dos deslocamentos comunitários e familísticos. Ainda se deslocam, como no "tempo das bandeiras", grupos de às vezes centenas de pessoas, sob liderança de um fazendeiro e patriarca, que tutela seus protegidos e sua clientela, como se viu nas últimas décadas, de Minas Gerais, da Bahia, do Espírito Santo para Goiás, o Para, o Mato Grosso. Às vezes, são grupos milenaristas, como os da Bandeira verde, Maria da Praia, do Divino Pai Eterno, e Romaria de Santina, de Justino, comunidades muitas vezes familiares, de vizinhança, religiosas ou de senhoria e prestação que se movem lentamente em direção à Amazônia, em busca de terras livres (p. 668).

O autor nos relata como as pessoas viviam e buscavam encontrar "a terra prometida", pois elas se reuniam e saíam passando por vários lugares em busca de um local, do qual não se ouviam muitos comentários. Esse processo migratório impulsionado pela seca e pela

\footnotetext{
${ }^{1}$ Entrevista realizada pela autora, com Ataíde em maio de 2014. 
concentração de terra na mão de poucas pessoas, provocava a falta de condições de moradia e sobrevivência da maioria da população dos habitantes do Nordeste, tudo isso se associava também com as superstições e crenças religiosas sobre as ditas "bandeiras verdes".

No entanto, ao chegarem à "terra da profecia", vivenciaram alguns conflitos, pois essas terras já estavam ocupadas por diversos povos indígenas, sendo assim, os migrantes tinham que aprender a lidar e conviver com os antigos habitantes desse território.

Segundo Soares (2004), a relação entre os índios Kaiapó, Karajá, Tapirapé nesse território do Araguaia na época era complexa. E foi nesse cenário em meio à união e tumulto que se deu a formação da região.

Éh! Eu passei muito medo de índio bravo, porque todo verão eles vinham, esses índios lá da beira do Xingu, Kaiapó, aqueles do beição. Eles rondavam por aí de noite, o povo via os movimentos deles por aí. Eu morria de medo. Eles vinham em Luciara, até esses Karajá tem muito medo deles, a aldeia deles (Karajá) era ali para baixo, onde têm uns pés de manga (margem do rio Araguaia), eles saiam e quando pressentia movimento dos Kaiapó eles ó, caía e ia dormir na praia lá do outro lado do rio, com medo. A santinha mesmo cansou de me falar, uma Karajá que tinha aí que era muita minha amiga. Comadre, quando eu pressentia, Kaiapó tá por aí pelas costas, nós ajuntava menino com tudo e ia dormir na praia lá do outro lado do rio. Para você ver ${ }^{2}$, (Dona Adília Apud. Barbosa p.58).

Podemos perceber que a partir do momento em que os moradores do povoado passaram a conviver mais com os povos indígenas Karajá e os Kaiapó foi-se percebendo que os Karajá eram mais amigáveis e podiam contar com eles, enquanto os Kaiapó continuaram sendo temidos pelos migrantes e também pelos índios Karajá.

A convivência era razoável entre os posseiros/campesinos e os índios Karajá e os Tapirapé no povoado. Segundo Soares (2004, p. 55)

Existia uma certa "convivência pacífica", entre os sertanejos/posseiros e os Karajá do então povoado de Mato Verde. O processo de expropriação das terras dos Karajá em Luciara foi lento, sendo os conflitos mais acirrados pela posse da terra, desencadeados nas décadas de 1980 e 1990, quando se intensificou o processo de titulação das terras e a demarcação de uma reserva indígena para os Karajá, estabelecidos no município de Luciara³ ${ }^{3}$ antiga Mato Verde.

Entretanto, a luz do depoimento de um dos primeiros moradores do então povoado de Porto Alegre do Norte podemos afirmar que o medo que os moradores tinham com relação aos

\footnotetext{
${ }^{2}$ Entrevista realizada Barbosa com Dona Odília na cidade de Luciara em maio de 1999.

${ }^{3}$ No processo de demarcação da Aldeia Karajá KrêHáWã em Luciara, em 1992, houve um conflito violento entre índios e posseiros que precisou da mediação da polícia federal. Estas informações foram obtidas no relatório da Equipe Pastoral da Prelazia de São Félix do Araguaia. Mimeo - Arq. Prelazia São Félix do Araguaia. 
povos indígenas e as experiências de contato com eles é algo presente bastante presente em suas memórias de vida, pois assim relata:

O índio era muito perigoso. Quando os velhos nossos pais iam para um canto, (para roça ou outro lugar), tinha que ficar um barraqueiro, junto com as mulheres, porque senão os índios matavam. Naquele tempo todo mundo andava armado. Os Xavantes eram de passagem feitos chuva, agora os Kaiapó aperreavam muito nós. E os Tapirapé viviam nesse Urubu Branco, mas não mexia com ninguém não, (João de Sousa Lima, morador de Porto Alegre do Norte.).

Nos primeiros tempos do povoado, os moradores enfrentaram muitas dificuldades, sendo que, as maiorias dessas pessoas tinham como objetivo adquirir apenas uma pequena área de terra que pudesse plantar e produzir alimentos para a sustentação de suas famílias. Não imaginavam eles que viriam novos desafios, os quais teriam que ser enfrentados, caso quisessem conseguir a tão sonhada terra. De tal modo, descreve um dos ditos pioneiros de Porto Alegre do Norte:

[...] naquele tempo não tinha negócio de fazenda, chegava um e dizia para o outro: compadre aqui é bom para morar, porque tem água e tem muita mata. Daí situou e derrubou a roça na Cedrolândia, mas não tinha nem nome ainda. Era um brejão só. Depois, derrubou o mato com o machado e queimou a roça, todinha. Antes nós morávamos na fazenda São Pedro e de lá nós viemos, para a fazenda São Salvador, onde moravam o Jacobi (vaqueiro do Lucio da Luz) e o velho Domingão. Ficamos um tempo por lá e depois saímos e fomos procurar outro lugar, foi quando encontramos a Cedrolândia. Quando chegamos, no mesmo dia (6 de janeiro de 1950), disso eu me lembro bem, a minha mãe e a minha madrinha rezaram um terço, porque era dia de Santo Reis e elas costumavam rezar para Santo Reis, e assim foi a nossa vida nesse sertão velho, desde o dia 6 de janeiro de 1950. E até hoje, ficamos por aqui, [...]” (João Angélica, morador de Porto Alegre do Norte, junho 2014).

Nota-se que não era objetivo dessas pessoas terem grandes fazendas. O que elas queriam na verdade era uma área de terra, onde pudessem dela retirar o sustento. Deste modo, ao escolher um lugar para morar, observavam se na terra havia uma boa nascente de água e, se encontrassem já habitavam no local, ficando por ali por um tempo, depois saíam em busca de um lugar melhor. Sempre na esperança de encontrar a terra sonhada, com a concepção de terra de uso para o bem comum. Onde também tinham as relações de amizade e parentesco entre as pessoas que ali habitavam.

Rezar também era uma forma de agradecer os santos pelas conquistas e pela vida; o relato também ajuda ilustrar a manifestação religiosa dos sertanejos que habitavam o povoado. O dia de Santo Reis é uma data importante para os seus devotos, que haviam acabado de conquistar um novo lugar para morar, revelando, assim, as características religiosas desse povo. 
É sabido que o dia de Santo Reis é uma manifestação cultural popular, festejada em várias regiões do Brasil, sobretudo nas áreas rurais.

[...] O nome "folia" aplica-se a um ritual religioso de grupos de pessoas, onde tinha grupos de artistas devotos, em nome de uma santidade de devoção coletiva, visitam casas onde recolhem dádivas, distribuem bênçãos, atualizam promessas e anunciam os festejos do "Santo" em nome de quem reconhecem "em jornada": Folia de Santo Reis, Folia do Divino Espírito Santo, Folia de São Sebastião, Folia de Outros Santos de devoção camponesa e tradição popular desde o Catolicismo Colonial (BRANDÃO,1993, p.37).

A tradição popular camponesa de devoção aos santos teorizada por Brandão, e em particular a festa de Santo Reis é uma festa em que as pessoas fazem uma caminhada de casa em casa, rezando por vários dias até chegar, no dia de Santo Reis, ao local em que a pessoa fez a promessa. Essas pessoas são acompanhadas por outras, uma vez que, por onde iam passando agregavam mais pessoas à caminhada. O grupo de foliões é composto de instrumentos, cantores, dançarinos e da bandeira do Divino Pai Eterno.

De acordo com Macruz (1983, p.100-101), "fazer o giro do divino significa passar o tempo da festa, que não é festa de guarda, percorrendo as casas que pediram visitas. O grupo vai a pé, carregando a bandeira [...]”, no caso do povoado de Porto Alegre a autora diz que os foliões saíam “[...] andando grandes distâncias para cumprir visita, pois nem todas as casas são na corrutela”. "O grupo recebido, com comida e bebida é também hospedado quando a posse é muito longe, mas de qualquer modo não se pode desmembrar durante todo o giro. Nas casas visitadas, grupo canta benditos e cânticos ao espírito santo, tocando seus instrumentos e bebendo pinga durante todo o trajeto".

Durante o período do giro os foliões fazem as apresentações nas casas por onde passam, essas apresentações em forma de cantorias sempre trazem uma mensagem de vida, a canção de Ivan Lins e Victor Martins (1978), ajuda-nos a refletir sobre o significado da fé, no sentido de percebermos que a terra, a natureza, a política e a religião são elementos imbricados nos modos de viver, traçando os próprios princípios da fé, da liberdade e da justiça na cultura do povo sertanejo.

Os devotos do Divino vão abrir sua morada

Pra bandeira do menino ser bem-vinda, ser louvada, ai, ai

Deus nos salve esse devoto pela esmola em vosso nome

Dando água a quem tem sede, dando pão a quem tem fome, ai, ai

A bandeira acredita que a semente seja tanta

Que essa mesa seja farta, que essa casa seja santa, ai, ai

Que o perdão seja sagrado, que a fé seja infinita

Que o homem seja livre, que a justiça sobreviva, ai, ai

Assim como os três reis magos que seguiram a estrela guia

A bandeira segue em frente atrás de melhores dias 
No estandarte vai escrito que ele voltará de novo

E o Rei será bendito, ele nascerá do povo, ai, ai

Na concepção de Brandão (1993, p. 90), “onde há cultura há processos sociais de produção e distribuição de conhecimento, onde há processos sociais que colocam em circulação pessoas, grupos, bens, serviços e símbolos há relações e controle de poder”.

Para Macruz (1983), os moradores de Porto Alegre resguardavam os dias dos santos por entender que a "[...] festa de guarda designa dia em que se não trabalha, por razões religiosas, supersticiosas ou por feriado". No entanto, quando os posseiros passaram a vender sua força de trabalho os hábitos culturais foram aos poucos sendo modificados, pois "[...] com o advento das fazendas em 1970, os peões passaram a não respeitar festa de guarda devido a sua forma de trabalho, pois ganha por serviço feito. Logo, qualquer acidente ocorrido nesses dias é atribuído ao fato".

Lembrando que entre os moradores do povoado de Porto Alegre havia também os devotos de outros santos como Santo Antônio, São João, São Pedro, São José e Nossa Senhora Aparecida, para os quais os moradores faziam promessas pedindo aos santos uma vida melhor. Segundo o senhor João Angélica as rezas terminavam em festa, assim diz:

[...]. Fazíamos promessas a um determinado santo, pedindo que algo melhorasse na nossa vida. Depois retribuíamos com uma reza em homenagem aquele santo. Na reza e no festejo recebíamos os parentes e amigos. Essas rezas geralmente eram continuadas de uma festa, incluindo músicas e alimentação típica da nossa cultura (aquele tipo de comida, que só nós que conhecemos, é quem gosta de comer, coisas de roça e de posseiro), (João Angélica, morador de Porto Alegre do Norte, Junho de 2014).

Entre as rezas se destacava a de Santo Antônio, realizada por um dos "pioneiros do povoado, sendo até hoje uma tradição da cidade". A festa do Domingão é uma reza seguida de três dias de festas, sendo que a mesma acontece todos os anos e é denominada também como o Festejo de Santo Antônio.

Ressalvamos que a mudança do nome dado ao povoado de Cedrolandia para Porto Alegre do Norte, está relacionado à prática de compras e trocas de mercadorias que aconteciam às margens do rio Tapirapé, onde os moradores ficavam esperando os barcos chegarem com as mercadorias.

[...]. É como eu te disse antes o nome era Cedrolandia, porque tinha cedro muito grande e grosso lá. E quem colocou esse nome foi o velho Lúcio da Luz... E nós ficamos nessa Cedrolandia por um bom tempo. Depois nós resolvemos sair de lá para morar na beira do rio Tapirapé. E colocamos o nome do Povoadinho de Beira do Rio. Esse município teve vários nomes, até de Cachorro Sentado, Cachorro de Coca, o povo da fazenda que botava esses apelidos no povoado. E nós ficávamos revoltados, até que um dia o Cícero 
laranjinha, tomando umas pingas, botou logo o nome de Porto Alegre (João Angélica, morador de Porto Alegre do Norte, Junho de 2014).

A luz do depoimento do senhor João Angélica asseguramos que a origem do nome está vinculada a questão mercadológica, uma vez que os barqueiros eram recebidos com muita expectativa, sempre se festejava a chegada de novas mercadorias, até porque um dos principais produtos comercializados na época eram as bebidas alcoólicas, sobretudo a cachaça, muitos moradores aproveitavam a ocasião para beber e se divertir. Daí a expressão Porto Alegre.

O relato a seguir nos revela que o cotidiano dos moradores do povoado não era só de festas, bebedeiras e rezas, pois havia também sofrimento em função das dificuldades encontradas.

Era uma pobreza danada nesse lugar. [...] Rapaz a nossa mobília das casas era: cabaça, roda de fiar algodão, pente de tear para fazer linha de algodão, panela e pote de barro. [...] nós íamos buscar água no rio e dizíamos vamos para a beira do rio, buscar água e ia todo mundo, crianças, homens e mulheres. Porque nós tínhamos medo dos índios atacarem, mas nunca aconteciam, porque todo mundo cuidava uns dos outros" (João Angélica, morador de Porto Alegre do Norte, Junho de 2014 $)$.

Ao povoar à beira do rio, os posseiros se deparavam com vários obstáculos, pois não havia conforto nenhum, restando aos mesmos a condição de fazer o enfrentamento frente aos desafios das matas, sendo que os mesmos temiam os ataques dos indígenas que viviam na região. Nota-se que as pessoas vinham em busca de terra para a criação de gado, é visível o vínculo dos novos moradores com o vaqueiro do Coronel Lucio da Luz, fundador do município de Luciara (antigo Mato Verde), município que deu origem ao povoado de Porto Alegre ${ }^{5}$.

Como havia também as pessoas que sonhavam com o "progresso", ou seja, com melhorias de acesso ao povoado, já que não se tinha estradas ali, estas esperavam chegar o dia em que iriam viver à luz do desenvolvimento regional, propagado pelos programas do governo e disseminado pelos veículos de comunicação da época.

Assim, construíram uma pista de avião através da ação coletiva, em que utilizaram como ferramentas básicas as enxadas para carpir e destocar. Havia entre os moradores o imaginário de que a pista iria trazer benefícios e emprego para as pessoas que moravam ali na época. Segundo relato de um dos moradores, o avião foi comprado sob a promessa de que o mesmo iria trazer benfeitorias para as pessoas do povoado e, por isso, ajudaram a abrir a pista.

\footnotetext{
${ }^{4}$ Entrevista realizada pela autora em junho de 2014

${ }^{5}$ Para uma melhor compreensão dessa questão ler Soares (2004) em Trilhas e Caminhos: o povoamento não indígena do povo do Araguaia na primeira metade do século XX. 
Porém, só houve melhorias para algumas pessoas, inclusive para os fazendeiros ${ }^{6}$ da região, conforme destacado no relato abaixo:

[...] comprou um avião e pediu para nós fazermos um campo de aviação, assim fizemos um mutirão e construímos dois campos, um na Cedrolândia e o outro aqui. O Zé Diton era compadre dele e tinha muita vaca, e fez outro campo lá e o outro na beira do rio, eu ajudei fazer, capinar aqueles trens, carregava aqueles trem no couro de gado, amarrava um pau, assim um pegava de um lado e o outro do outro lado. Depois quando a fazenda Frei nova chegou. O Plínio Ferragem foi lá e pediu para aumentar a pista, eles diziam que iam comprar uns aviões grandes e ia ficar bom para nós. Porque tinha muito serviço, tinha recurso, quem quisesse olhar gado iria trabalhar com gado, dizendo sempre que para quem não quisesse mexer com gado tinha outros serviços, e o povo animou pensando que os fazendeiros queriam o bem de todos, abrimos a pista. Ai sim descobrimos que ficou pior pra nós, só perseguição e briga demais [...] (João Angélica morador de Porto Alegre do Norte, Junho de 20147).

Como vimos no relato, os posseiros fizeram duas pistas de avião, carpindo com a enxada, onde os fazendeiros falavam que essas pistas eram para melhorar a vida do povoado. No entanto, foram trapaceados pelos fazendeiros que usaram da mão de obra dos mesmos, para que construíssem as pistas de avião, dizendo que esta iria melhorar a vida dos posseiros, mas não foi o que ocorreu. Só os fazendeiros se beneficiaram ao explorar a população que vivia ali produzindo o seu próprio sustento, em um sistema de uso comum da terra.

[...] houve muita mudança no modo de viver, hoje está tudo diferente. Não tinha preocupação com o desenvolvimento da região, isso não era preocupação nossa, a não ser o medo do índio e da onça, pois quanto menos pessoas existiam no povoado, maior era o risco de sermos atacados. Mas o índio, aqui não era tão violento, e logo se misturou os Kaiapó, os Xavante, os Carajás e os Tapirapé. O xavante não era muito violento, os Kaiapó eram os mais violentos, enquanto os Tapirapé conviveram conosco por um bom tempo, mais não tinha o hábito de apanhar nada, e não costumavam atacar ninguém. Esses (os Tapirapé) vinham para onde estava o pessoal (eles sempre moravam perto de nós), porque os índios Tapirapé viviam com medo dos índios Kaiapó. Eles eram civilizados e falavam em português. As nossas roças não eram divididas em cercas. A gente fazia as roças juntas, só dividia assim, a parte do arroz, a parte da mandioca, a parte do milho, tinha a parte do feijão e outras coisas. Os homens trabalhavam juntos tanto na roça como no serviço de vaqueirar o gado. As mulheres e as crianças pequenas ficavam em casa. Quando as mulheres iam lavar roupa, os homens ficavam por perto, pescando ou caçando e as crianças aproveitavam para tomar banho no rio, (João Angélica, morador de Porto Alegre do Norte, Junho de 2014).

\footnotetext{
${ }^{6}$ Os fazendeiros vinham em busca de conseguir mais terras para expandir a sua criação de gado, mas tinha dois tipos de fazendeiros o que criava gado buscava por mais pasto para criar seus gados e soltava o gado no varjão, pois se tinha a visão de terra comum e os fazendeiros que focou no agronegócio.

${ }^{7}$ Entrevista realizada pela autora em junho de 2014.
} 
Percebe-se, mais uma vez, através desse relato, que os posseiros faziam atividades diversas, não específicas como, o caso de caçar, derrubar a roça, plantar, colher, olhar o gado, vender alguns produtos da roça e animais que caçavam. Não havia, pois, a divisão de tarefas na realização das atividades tudo era feito de forma coletiva. Onde os posseiros desenvolviam todas essas atividades e estabeleceram uma relação com os indígenas Tapirapé, Kaiapó, Karajá e os Xavantes, relações essas que eles estabeleceram entre alguns deles como recurso de sobrevivência pois tinham medo dos índios Kaiapó.

Não se percebe na fala do entrevistado a existência de uma preocupação quanto a demarcação de terra, até porque esses sertanejos que viviam naquela região não possuíam a ambição de demarcação, assim como não buscavam regularizar a posse da terra através do título. Percebe-se que as terras na época não tinham documento, tampouco as pessoas tinham conhecimento dos seus direitos, havendo assim, muita fraude nos títulos de terra.

Sobre essa questão Soares (2004, p.89), diz que:

Nessa época proliferaram as transações fraudulentas de terra, por meio da venda de títulos provisórios "frios" (...) Os 'títulos voadores' que remontavam outros títulos expedidos pelo ex-D. T.C. entraram no mercado de terras e eram disputadíssimos por grileiros, para dar "legalidade" a gleba usurpada, como também por adquirentes de boa-fé. Todos buscavam ajustá-los a algum pedaço de terra que se encontrasse desocupado e sem incidência de titulação. Uma vez que a localização da área, constante do título, era muito vaga, indicando mais sua extensão e o município, sem menção dos confinantes e sem precisão das coordenadas, com o correspondente marcos no chão, vários títulos podiam cobrir a mesma área, assim como várias áreas podiam se ajustar ao mesmo título ${ }^{8}$.

Analisando as produções acadêmicas sobre essa questão, percebe-se que o processo pelo qual, as pessoas tentavam legalizar suas terras no Estado de Mato Grosso era constituído de irregularidades, o que gerou conflitos no campo e demandas judiciais.

Apesar das dificuldades de regularizar a terra, essas pessoas continuavam na lida no campo, realizando diferentes afazeres, conforme relato de um dos antigos moradores: "[...] não tinha a ideia de criar gado naquela época. O povo dizia assim que quem criava gado era rico. Naquele tempo eu misturava tudo roça e gado (João Angélica morador de Porto Alegre do Norte, Junho de $\left.2014^{9}\right)^{\prime}$.

$\mathrm{Na}$ época os moradores do povoado de Porto Alegre utilizavam muito a troca de produtos entre si, trocavam mantimentos da roça pelos produtos industrializados que eram trazidos pelos barqueiros, sendo que o valor de "riqueza", ou seja, o bem de valor que gerava

\footnotetext{
8 MORENO. Op. Cit. pp. 248-49.

${ }^{9}$ Entrevista realizada pela autora em junho de 2014 
capital na época era o gado, e também as pessoas desenvolviam várias funções e a lavoura era para subsistência deles. É o que demonstra esse trecho do relato do senhor João Angélica.

[...] Naquela época tinha muitas coisas, bem mais vendidas, fora o gado, o que era trocado naquela época nos tínhamos o couro do jacaré, da onça, o gato do mato, essa ariranha, Porcão, caititu eram tudo vendido na forma de troca. Arroz, milho, feijão era iguá, os mantimentos de hoje, era de tudo só que era mais bem tratado do que hoje. Nessa época era bom, tinha o povo lá do Mato Verde que vinha de canoa ou de barco, eles desciam até o Tapirapé, vinham o Zé Arculano, Manoel Costa. Eles vinham para beber e festar na beira do rio. $O$ produto que mais agente usava como forma de troca era o gado. O comércio de gado já era forte, mas era tudo na base da troca [...] (João Angélica, morador de Porto Alegre do Norte, de 2014 ${ }^{10}$ ).

Observa-se que as pessoas utilizavam outros meios para obter uma renda maior, visando o sustento da família. Os produtos comprados por essas pessoas eram apenas os industrializados como tecidos, perfumes, bebidas alcoólicas e outros, adquiridos através da troca, sobretudo, por pele de animas extraídos da fauna. Neste período é possível perceber que as pessoas já buscavam outros meios de adquirir mais alimentos e melhorar a qualidade da renda financeira.

\begin{abstract}
A economia nossa aqui da região era o marisco, que vinha da caça e pesca. Esse processo econômico foi proibido a partir de 1970. A partir de então a economia do povo ficou baseada na roça, mas a motivação do povo vir para a região era pela questão religiosa, aqui tinha muito povo messiânica do Araguaia, que tinha como inspirador religioso o padre Cícero, assim conta a profecia relatada pelos entrevistados que o mesmo incentivava os "retirantes", a procurar as bandeiras verdes do Araguaia. Esse povo que vinha para cá tinha essa questão de comercializar o marisco, depois do marisco veio a Pecuária da larva, são essas atividades econômicas que eram desenvolvidas na região, (João Angélica, morador de Porto Alegre do Norte, de $2014^{11}$ ).
\end{abstract}

O que pode ser percebido no relato a seguir é que os sertanejos que constituíam a população do povoado, e estavam envolvidos no processo econômico tinham como atividades diversas o marisco, a roça, e a pecuária como principal fonte de renda. Já quando se tratava da criação bovina, o gado nem sempre era dos posseiros quem tinha a posse era os fazendeiros que nos contratavam para cuidarem dos seus rebanhos, com um acordo entre eles, que se caracterizava na forma de "criar gado", onde eles pagavam os posseiros em forma "cria e sorte", ou seja a cada quatro bezerros que nasciam o posseiro tinha o direito de ficar com um.

Nessa conjuntura era bastante comum o posseiro criar entre eles as redes de amizades e parentesco. Como afirma no trecho do relato abaixo:

\footnotetext{
${ }^{10}$ Entrevista realizada pela autora em junho 2014

${ }^{11}$ Entrevista realizada pela autora em junho 2014 
[...] Não tinha parente aqui, era só nós mesmos, veio meu pai a minha mãe e a Irmão dela o Chico Laranjinha que eram os parentes. E aí veio o Domingão que chegou junto, ele era vaqueiro do Lucio da Luz. A gente estava na Cedrolândia e de lá ele veio para a beira do rio, mas o Chico Laranjinha, foi fazendo casa e a partir de então foi chegando mais gente. Naquela época nós íamos buscar água lá na beira do rio na cabaça, trazíamos no meio da carga íamos lavar roupa, lá colocávamos as cabacinhas no meio da carga, cansei de andar no meio da carga com umas cabacinhas. E gostava também de brincar com os cavalinhos de pau. Essas brincadeiras faziam parte da minha vida[...] (João Angélica, morador de Porto Alegre do Norte, de 2014 ${ }^{12}$ ).

Notamos através do relato que ao chegarem ao povoado, os migrantes não tinham parentes que moravam por ali, a não ser os casos dos parentes que migraram junto com eles. Essa situação nos remete a concepção de Bourdieu (1996), quando o autor fala da relação entre as famílias, do laço forte que as une, pois, o aspecto familiar agrega as pessoas, dando amparo e sustentabilidade aos seus membros nos diferentes momentos da vida. Assim reafirma o autor:

Esses estilos de vida foram evidenciados por Bourdieu no designado "espírito de família", porquanto assegura sentimentos e obrigações comuns para os membros familiares. A mulher é um agente importante na edificação do 'espírito familiar', especialmente nos relacionamentos que ela procura manter não somente com sua família, bem como com a do seu cônjuge: telefonemas nos aniversários, em datas festivas, fotografias em reuniões familiares, inúmeras trocas simbólicas, por meio de ajudas e visitas. Evidentemente, que a mulher não é o único agente que consolida este tipo de "espírito". O que vale reforçar é que neste, são configurados o próprio trabalho de instituição da família, mediante os quais ela se reafirma de maneira duradoura (BOURDIEU, 1996, p, 185).

A luz da concepção de Bourdieu podemos dizer que a família é um laço que está presente em todos os locais, e isso é um ato simbólico muito importante para todos nós. A importância das relações entre os membros da família no seu meio social.

Contudo, podemos afirmar que esses sertanejos possuíam relações de afetividade, amizade e compreendiam que o relacionamento familiar, independente dos laços sanguíneos era de suma importância para sua sobrevivência.

Consideramos ser importante destacar que os moradores entrevistados em nossa pesquisa, ao relatarem os horrores vivenciados diante das situações de conflitos entre os posseiros e os fazendeiros ocorridos durante o processo de formação do povoamento de moradores de Porto Alegre do Norte. Torna-se fundamental reafirmamos a importância das pesquisas sobre a memória, sobretudo as que fazem uso de fontes orais, pois segundo Montenegro (2010, p.27), “[...] as entrevistas permitem instruir um novo campo documental

\footnotetext{
${ }^{12}$ Entrevista realizada pela autora em junho 2014 
que, muitas e muitas vezes, tem-se perdido com o falecimento dos seus narradores". A entrevista nos permite viajar na memória relatando o que aconteceu no seu passado e compreendendo o momento do presente.

Para Halbwachs (1990, p.60) “[...] não é na história aprendida é na história vivida que se apoia nossa memória". Pois são os acontecimentos que marcam a vida das pessoas, uma vez que a memória coletiva para o autor são construções dos grupos sociais, dessa forma vão sendo reconstruídas a partir das suas lembranças, nesse sentido ao relatarem durante as entrevistas eles retomam ao passado, a partir do momento em que o entrevistado relata se faz renascer todo um contexto imaginário. E corroborando com essa ideia Pollak (1992, p.204), afirma que a memória “[...] é um elemento constituinte do sentimento de identidade, tanto individual como coletiva $[\ldots] "$.

Como podemos observar no documento que se encontra no Arquivo da Prelazia de São Félix do Araguaia, o qual vem falar sobre os conflitos da terra que desencadeou na região, e as promessas dos "gatos" que viajavam para outros estados, em busca de mão de obra e propagavam promessas fantasiosas para iludir as pessoas com juras de melhoria de vida.

Figura 02- $\mathrm{O}$ conflito entre professores e fazendeiros

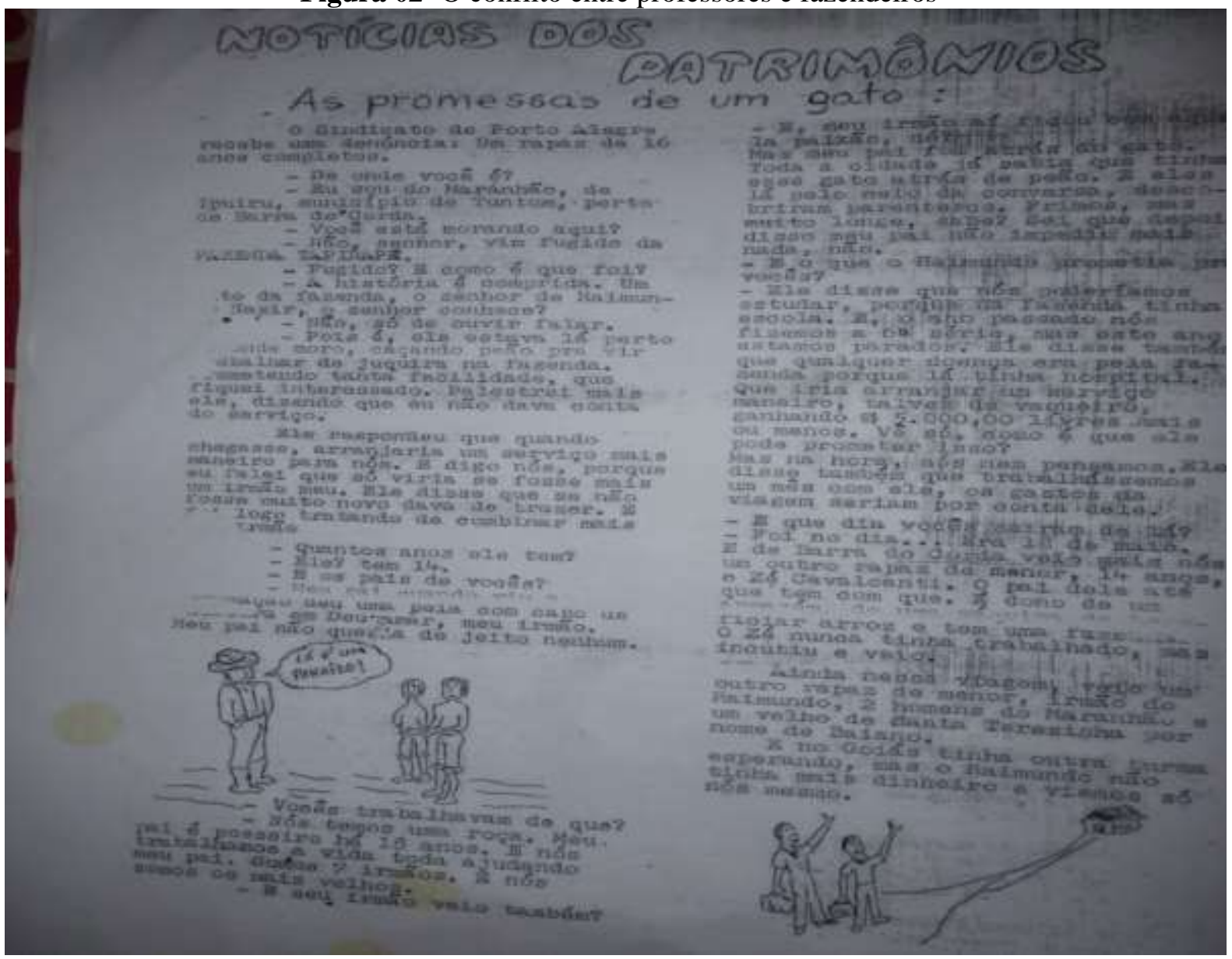

Fonte: Arquivo da Prelazia de São Félix do Araguaia, 2015. 
Nota-se no documento como os "gatos" agenciavam as pessoas, trazendo-as de seus lugares de origem para trabalharem nas fazendas com promessas de melhoria de vida.

Neste período os fazendeiros recorriam muito ao serviço "de gato", uma categoria que tinha como função agenciar os trabalhadores rurais para as fazendas; esses "gatos" procuravam pessoas para trabalhar, fazendo promessas que tudo seria maravilha, porém quando chegavam ao local de trabalho a realidade era diferente, como salários baixos ou a não existência de salários, falta de condições de trabalho, alimentação inadequada, ou seja encontravam na verdade condições desumanas e degradantes. No entanto, as pessoas acreditavam e acabavam se tornando escravas nas grandes fazendas da região do Araguaia ${ }^{13}$.

Desse modo, possamos observar nos relatos que as pessoas tiveram que lutar arriscando a própria vida, enfrentando os fazendeiros que recorriam aos jagunços para atentarem contra as suas vidas; muitas vezes até os policiais se prestavam a esses tipos de "serviços" para com a população desprovida de capital financeiro, já que atuavam em favor dos fazendeiros, conforme descrito por Edésio Guimarães: “[... ] então tinha um policial de Luciara aqui, pois era município de Luciara. Pois os policiais faziam, e aconteciam nessa época, ou seja, matavam, sumiam com trabalhadores a mando dos fazendeiros, falou Edésio... [...] (Edésio Guimarães morador de Porto Alegre do Norte, de 2014)".

É importante ressaltar que mesmo com todos esses desafios e até ameaça de morte que se depararam todos esses longos anos, os posseiros não desistiram de lutar pela terra e para que o Estado mudasse a política da época. No relato da sua trajetória de vida, Edésio Guimarães afirma que as práticas dos fazendeiros e policiais eram no sentido de amedrontar os posseiros, para que estes desistissem da luta pela posse da terra, onde viviam e produziam o sustento de suas famílias. Nesse sentido diz que:

[...] quando chegamos aqui era só nos mesmos. Meu pai, disse a nós para fazermos uma pista de avião, e fomos ainda pequenos e fizemos, era bem aqui mesmo pertinho. O povo só perseguindo, os fazendeiros perseguiam o índio rapaz, depois veio à fazenda passou uma cerca entre a casinha e a casa aí. Um dia a mulher veio, ai enganchou a roupa e eu cortei a cerca rapaz, quando pensei que não, encheu de polícia para me pegar aí eu disse não vou para a delegacia, eu não vou sozinho não, aí fui lá na polícia e falei que não ia. Eu, papai com meninos e a mulher vinham tocando aqui, era duro nós sofrermos, aqui eu sofria demais. Não tinha outra coisa era rede, saco, a cama era feita de vara, fazia aquele colchão de capim pubo e colocado aí para deitar em cima mais a moça, nós sofremos demais. [...] (Júlio morador de Porto Alegre do Norte, de 2014).

\footnotetext{
${ }^{13}$ Para uma melhor compreensão sobre as relações de trabalho escravo nas agropecuárias da região do Araguaia, ver Maria Aparecida Martins Souza (2009), dissertação de mestrado intitulada de: Retalhos de vidas: Escravidão Contemporânea nas Agropecuárias do Araguaia (1970-2005).
} 
Nota-se ainda que as pessoas tinham a esperança de que se elas abrissem a mata, e construíssem a pista de avião iria melhorar suas vidas, no entanto, a partir do momento em que se abriu a estrada e construiu a pista de avião ficou mais difícil ainda, pois facilitou o acesso para os fazendeiros, policiais e mais posseiros na época na disputa pela terra.

Não se pode perder de vista também a importância que a Igreja Católica, em especial a Prelazia de São Félix do Araguaia que teve sempre em defesa da luta dos posseiros, não só de Porto Alegre do Norte, mas de todo a microrregião Norte Araguaia. Segundo os relatos dos primeiros moradores, o sofrimento era muito, às vezes a pessoa pensava que nem iria chegar na fase da velhice, pois era duro e constante o conflito que tinha entre os posseiros e fazendeiros.

À luz dos depoimentos daquilo que as pessoas viveram, vê-se que a luta pela terra deixa, na trajetória de vida das pessoas, marcas que não conseguem ser apagadas; as marcas acompanham essas pessoas até hoje gravadas em suas memórias.

Ao ouvir contar as experiências de vida, é impossível não perceber o quanto era intenso o medo que as pessoas sentiam do conflito armado, que havia entre os encarregados das fazendas, os jagunços e os posseiros.

[...] ouvi falar o nome da cidade já dentro da cidade, eu vi muitas coisas acontecerem aqui na época, aqui tinha muitos pistoleiros famosos, o policiamento também era comandado pelos grandes fazendeiros, as policiais da época não olhavam para quem eles iriam bater, maltratar não queriam nem saber se aquela pessoa tinha feito alguma coisa ou não[...] (Edésio Guimarães morador de Porto Alegre do Norte, de 2014).

O que mais nos chama a atenção é o fato do policiamento da cidade, o qual deveria proteger a segurança da população, estava a serviço da minoria, minoria essa detentora do poder econômico, no caso, os donos das fazendas, que comandavam o policiamento e davam ordens para maltratar, judiar e até matar os posseiros que necessitavam e lutavam bravamente por um terreno para viver e sustentar a sua família.

Nesta mesma perspectiva, o relato abaixo ajuda-nos a ilustrar a relação dos policiais com a população que vivia no povoado:

[...] olha eu vi um bocado de coisa, quando cheguei aqui na Frei Nova na época das orelhas, esse costume era muito famoso um tal de Juca pistoleiro que, inclusive esse prefeito de Porto Alegre, ele era pistoleiro também, você não sabia né, e era comandado pelo Luiz Carlos Machado, Luiz Banguê aí pode só buscar atrás que ele veio para a região como funcionário do Luiz Banguê. Agora é prefeito. Aqui tinha muito assassinato de gente, um coisa ruim, a polícia aqui na época num identificava a pessoa ia batendo, já iam fazendo coisas absurdas inclusive tinha um inspetor da Sucam que teve aqui, eles bateram demais nele, eu pensei agora as coisas vão melhorar aqui em Porto Alegre, mas mesmo assim mexerem com um funcionário do órgão federal, é a 
coisa era difícil. [...] (Edésio Guimarães morador de Porto Alegre do Norte, de 2014).

Segundo o relato acima, havia naquele período muitos pistoleiros, sendo que os mesmos tentavam intimidar os posseiros da região a mando dos patrões. Nota-se que o documento abaixo vem relatando os anos e os acontecimentos em ordem cronológica, dos conflitos que ocorreram entre os donos de fazendas e os posseiros. A intenção dos fazendeiros era conseguir tomar as terras dos posseiros, mas estes por várias vezes tiveram que reagir contra os jagunços, colocando suas vidas em risco para garantir suas terras.

Figura 03- Posseiros enfrentam fazendeiro.

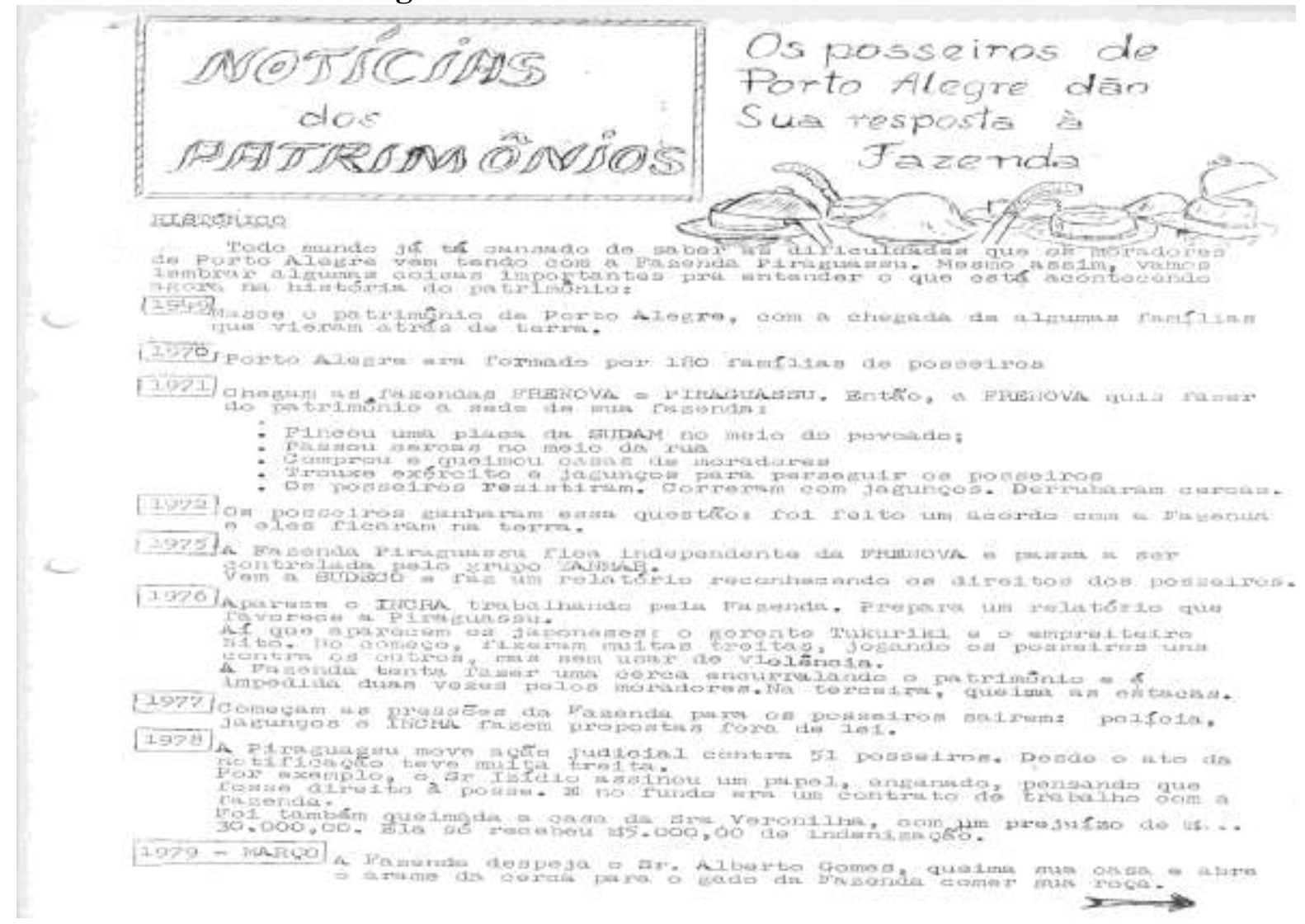

Fonte: Arquivo da Prelazia de São Félix do Araguaia, 2009.

Percebe-se a partir da imagem do Arquivo da Prelazia de São Felix do Araguaia que houve toda uma luta pela terra, e o sofrimento dos posseiros foi grande com os ataques dos fazendeiros que queriam toda a terra para si.

O relato do senhor Edésio Guimarães ajuda-nos a ilustrar a convivência da população de Porto Alegre, a qual praticava o evangelho e era voltada também para a formação da 
consciência política das pessoas, que não possuíam condições financeiras, pois eram desprovidos do capital financeiro e da assistência do Poder do Público. Assim diz Edésio:

[...] cheguei estava ai, disse não sou católico, fui pra igreja na hora da oração, então chega o Pedro Fernandes que era o presidente do sindicato, na hora do sermão vem o Pedro Fernandes falar com megafone, e passou aquele problema de terra, e eu disse que putariaé essa igreja discutindo problema de terra, ai resolvem em outra hora aqui. Na igreja tinha um bêbado que chegou na hora da comunhão, e o bêbado queria ir lá, e eu empatando o bêbado para o bêbado não ir comungar, sabe a verdade depois que eu fui entender que faz parte da igreja, tem lugar que é mais estudantes, tem lugar que ela desenvolve e aqui o envolvimento da igreja era pela luta de terra com os indios, que até hoje, até hoje a igreja de São Felix é envolvida com problemas de índios e de posseiros, os posseiros acabaram o problema até hoje. $O$ pessoal na época era muito unido, o pessoal hoje não são, eu não sei o porquê, também hoje um não precisa mais do outro fácil, mas antigamente aqui era muito movimentado e a questão de amizade, a questão de luta, a luta era nossa, estávamos juntos hoje as pessoas não vão mais na casa do outro, a gente vê que também a televisão não deixa [...] (Edésio Guimarães, morador de Porto Alegre do Norte, de 2014).

O entrevistado fala ainda que ao chegar à cidade de Porto Alegre, e ir participar pela primeira vez na Igreja a primeira impressão foi de que era muito estranho, comparando com o que ele estava acostumado em sua região, pois as pessoas tratavam dos problemas de terra na Igreja, depois é que ele passou a entender que era o local onde as pessoas colocavam todos os problemas do conflito para as demais pessoas da cidade.

No entanto, percebe-se que as questões de conflitos entre posseiros e fazendeiros foram se modificando e diruindo com o passar dos tempos, a violência foi aos poucos perdendo força e o Estado passou a intervir nessas questões de forma mais eficaz.

\section{Considerações finais}

Neste trabalho procuramos retratar um pouco de como se deu o processo de formação e povoamento da cidade de Porto Alegre do Norte, bem como as várias mudanças pelas quais passou a cidade, tanto na sua formação como nas festas que ali acontecem como representação de sua cultura. Onde pudemos perceber que há muitas coisas a serem exploradas no que se referem aos modos de viver dos primeiros moradores, no entanto não é possível em um trabalho monográfico explorar todas as informações do processo de ocupação e formação da cidade de Porto Alegre do Norte.

É sabido que a partir da sua formação houve também as transformações na cidade, o trabalho trouxe também relatos dos conflitos e os enfrentamentos que os posseiros tiveram para se formar o povoado, enfrentamentos estes entre fazendeiros e posseiros na luta pela posse da terra. 
Portanto tivemos que fazer algumas entrevistas para obtermos as informações que não encontramos institucionalizadas nem nos arquivos das instituições públicas e nem nas instituições de cunho privado, e por isso, essas informações de como era a cidade de Porto Alegre do Norte e como ela está hoje, só foi possível graças aos recursos metodológicos orientados pela concepção das pesquisas que estruturam as técnicas e métodos dos estudos realizados através das fontes orais, sendo a história de Porto Alegre do Norte.

Logo, a falta de pesquisa sobre a origem do município remete a situação de que a história regional é desconhecida pela a maioria dos jovens. A partir dessa falta de conhecimento percebe que a maioria dos jovens não sabe destes acontecimentos, daí o maior sentido em buscarmos conhecer esses processos que explicam a dinâmica de surgimento e de formação dos municípios, extrapola a condição ser uma mera curiosidade, pois trata-se da identidade cultural de uma região.

\section{Referências Bibliográficas}

BRANDO, Carlos Rodrigues. Prece e Folia: festa e romaria. Aparecida, SP: Ideias \& Letras, 2010.

BOURDIEU, Pierre. Esboço de uma Teoria da Prática. In: Ortiz, Renato (org.). Sociologia. São Paulo: Ática, 1983

Editora, 1996

Razões Práticas Sobre a Teoria da Ação. São Paulo: Papirus

Coisas Ditas. São Paulo: Brasiliense, 1987.

EDWARDS, Elizabeth, HART, Janice. Photo graphs objects, histories: On the materiality of images. London: Routledge, 2005.

GIL, Antônio Carlos. Métodos e técnicas de pesquisa social. 5.ed. São Paulo: Atlas, 1999.

HALBAWCHS, Maurice. A Memória Coletiva. Tradução de LAURENT LÉON

SCHAFFTER. Editora vértice/revista dos tribunais. São Paulo SP, 1990.

LEONEL, Guilherme Guimaraes. Festas e sociedade: reflexões teóricas e práticas para a pesquisa dos festejos como fenômenos urbanos contemporâneos. 2010. Acesso em 26/07/2014. File: // c: /Users/unemat.

MARTINS, José de Souza. "A morte e o morto -tempo e espaço nos ritos fúnebres da roça". In Martins, José de Souza (org.) A morte e os mortos na sociedade brasileira. São Paulo, Hucitec, 1983, pp. 258-69.

Fronteira a degradação do outro nos confins do humano. São Paulo. Hucitec, 
MONTINEGRO, Antônio Torres. História oral e memória: a cultura popular revisada. 6 . Ed, $1^{\text {a }}$ reimpressão. São Paulo: Contexto, 2010.

MAUSS, Marcel. Sociologia e Antropologia. Vol. I e II. EPU/EDUSP. 1974.

MENDES, Eugênio Vilaça. As redes de atenção à saúde. Brasília: Organização PanAmericana da Saúde, 2011. 549 p.: il. Disponível em <ww.paho.org/bra/index.php? option=com_docman\&task=doc_download...>Acesso em: 20/02/2016.

NEVES, Lucília de Almeida. História oral: memória, tempo, identidades. Belo Horizonte: Autêntica, 2006.

POLLAK, Michael. Memória e Identidade Social. Estudos Históricos, Rio de Janeiro, v. 5, n.10, p. 200-212, 1992.

RIBEIRO, Maria Regina Rodrigues. As Representações Sociais sobre o desenvolvimento em Santa Maria - RS. Dissertação (mestrado) - Universidade do Vale do Rio dos Sinos, Programa de Pós-Graduação em Ciências Aplicas em São Leopoldo, RS, 2005. 